\title{
Oryzihumus leptocrescens gen. nov., sp. nov.
}

Correspondence
Yoko Takahashi
ytakaha@lisci.kitasato-u.ac.jp

\author{
Akiko Kageyama, ${ }^{1}$ Yoko Takahashi, ${ }^{1}$ Tamae Seki, ${ }^{1}$ Hiroshi Tomoda ${ }^{1}$ \\ and Satoshi Ōmura ${ }^{1,2}$
}

Kitasato Institute for Life Sciences, Kitasato University ${ }^{1}$, and The Kitasato Institute ${ }^{2}$, 5-9-1 Shirokane, Minato-ku, Tokyo 108-8641, Japan

\begin{abstract}
Three novel strains were isolated from a soil sample collected in Japan using GPM agar plates supplemented with superoxide dismutase and/or catalase. The strains were Gram-positive, catalase-positive, irregular rod-shaped bacteria with meso-diaminopimelic acid as a peptidoglycan diagnostic diamino acid, and the acyl type of the peptidoglycan was acetyl. The major menaquinone was $\mathrm{MK}-8\left(\mathrm{H}_{4}\right)$. Mycolic acids were not detected. The $\mathrm{G}+\mathrm{C}$ content of the DNA was 72-73 mol\%. On the basis of morphological and chemotaxonomic properties and a phylogenetic analysis using 16S rRNA gene sequences, these strains were classified as a novel genus and species, Oryzihumus leptocrescens gen. nov., sp. nov., in the family Intrasporangiaceae of the order Actinomycetales. The type strain is $\mathrm{KV}-628^{\top}$ (=NRRL $\mathrm{B}-24347^{\top}=\mathrm{JCM} 12835^{\top}=\operatorname{NBRC} 100762^{\top}$ ).
\end{abstract}

Various techniques for the isolation of novel microbial strains have been reported in order to facilitate the discovery of novel bioactive compounds from micro-organisms. An efficient method of discovering novel bioactive metabolites is through the isolation of new micro-organisms, and numerous approaches have been attempted to date (Huck et al., 1991; Iwai \& Takahashi, 1992; Jiang \& Xu, 1996; Nioh et al., 1995; Nonomura \& Hayakawa, 1988; Suzuki et al., 1998; Takeuchi \& Hatano, 1999). In a previous report, a new isolation method using agar medium containing oxidant scavengers, such as superoxide dismutase (SOD) or SOD plus catalase, was described (Takahashi et al., 2003). Using this method, we succeeded in increasing the number of bacterial strains isolated from soil samples.

Among 45 strains isolated from paddy soil in Saitama Prefecture, Japan, using this new isolation method, 20 strains belonged to the class Actinobacteria. Three strains were irregular rods, found to have meso-diaminopimelic acid in the peptidoglycan; in the phylogenetic tree based on $16 \mathrm{~S}$ rRNA gene sequences, they were loosely associated with Ornithinicoccus hortensis. Ornithinicoccus hortensis cells are cocci containing ornithine in their peptidoglycan.

In this paper, we report on the morphological, physiological and biochemical characteristics, cell composition, DNADNA hybridization and $16 \mathrm{~S}$ rRNA gene sequences of the

Published online ahead of print on 2 September 2005 as DOI 10.1099/ ijs.0.63799-0.

Abbreviation: SOD, superoxide dismutase.

The GenBank/EMBL/DDBJ accession numbers for the 16S rRNA gene sequences of Oryzihumus leptocrescens KV-628 ${ }^{\top}, \mathrm{KV}-641$ and KV-656 are AB193172, AB193173 and AB193174, respectively. three isolates in comparison with those of Ornithinicoccus hortensis. On the basis of the characteristics studied, these isolates represent a novel genus and species, Oryzihumus leptocrescens gen. nov., sp. nov.

Strains KV-628 ${ }^{\mathrm{T}}, \mathrm{KV}-641$ and $\mathrm{KV}-656$ were isolated from soil samples collected from a paddy field in Saitama Prefecture, Japan. Soil samples ( $2 \mathrm{~g}$ ) were suspended in $18 \mathrm{ml}$ sterile water and then mixed. Soil particles were allowed to sediment, the liquid phase was diluted $10^{5}$ times and $100 \mu \mathrm{l}$ was spread onto the surface of four kinds of GPM agar ( $1.0 \%$ glucose, $0.5 \%$ peptone, $0.5 \%$ meat extract, $0.3 \%$ $\mathrm{NaCl}, 1 \cdot 2 \%$ agar; $\mathrm{pH} 7 \cdot 0$ ) plate (Takahashi et al., 2003), as follows: (1) unsupplemented; (2) supplemented with SOD (300 U per plate); (3) supplemented with catalase (2100 U per plate); or supplemented with SOD plus catalase. Each plate was cultured at $27^{\circ} \mathrm{C}$. Biomass for biochemical and chemotaxonomic testing was prepared by culture in ToddHewitt broth (Difco) or nutrient broth (Difco) at $27^{\circ} \mathrm{C}$ for 3 or 4 days, followed by harvesting by centrifugation.

Morphological observation under a scanning electron microscope (model JSM-5600; JEOL) was performed on cultures grown on GPM medium at $27^{\circ} \mathrm{C}$ for 6 days. The ability of the strain to grow on a range of sole carbon sources at $1 \%(\mathrm{w} / \mathrm{v})$ was determined in carbon-utilization media (Pridham \& Gottlieb, 1948) with yeast nitrogen base agar without amino acids (Nihon Pharmaceutical). $\mathrm{NaCl}$ tolerance and $\mathrm{pH}$ and temperature ranges for growth were determined on 1/5 nutrient agar. The three isolates were characterized biochemically using API ZYM (bioMérieux) according to the manufacturer's instructions. Susceptibility to antibiotics was tested by culture in YD agar $(1.0 \%$ glucose, $1 \cdot 0 \%$ yeast extract, $1 \cdot 5 \%$ agar; $\mathrm{pH} 7 \cdot 0)$ medium 
supplemented with the following antibiotics: erythromycin, aztreonam, rifampicin, novobiocin, streptomycin and chloramphenicol.

Whole-cell hydrolysates were analysed for diaminopimelic acid isomers using TLC (Becker et al., 1965; Hasegawa et al., 1983); the $N$-acyl types of the muramic acid were determined by using the method of Uchida \& Aida (1977). Purified cell wall was obtained by following the method of Kawamoto et al. (1981), and the amino acid composition of the hydrolysed cell wall was determined using an automatic amino acid analyser (model L-8500A; Hitachi). Whole-cell sugars were analysed by using the method of Becker et al. (1965), the presence of mycolic acid was examined by using the TLC method of Tomiyasu (1982), and phospholipids were extracted and identified by following the method of Minnikin et al. (1977). Menaquinones were extracted and purified according to the method of Collins et al. (1977) and were then analysed by HPLC (model 802-SC; Jasco) on a chromatograph equipped with a CAPCELL PAK C18 column (Shiseido) (Tamaoka et al., 1983). The cellular fatty acids were determined. The strains were cultured on $1 / 5$ nutrient agar plates. Methyl esters of cellular fatty acids were prepared by direct transmethylation with methanolic hydrochloride and were analysed by GLC (model GC-17A; Shimazu) with a DB-23 capillary column $(0 \cdot 25 \mathrm{~mm} \times 30 \mathrm{~m}$; J\&W Scientific) (Suzuki \& Komagata, 1983).

PCR amplification for selection of Actinobacteria was performed. DNA was prepared by sonication (Yu et al., 2002). A part of domain III of the 23S rRNA gene was amplified by using the method of Yu et al. (2002).

The DNA G + C content and DNA-DNA relatedness values were determined. DNA was isolated as described by Saito \& Miura (1983), with some modifications. The G + C content was estimated by using HPLC (Tamaoka \& Komagata, 1984). Levels of DNA-DNA relatedness were determined by the method of Ezaki et al. (1989), using photobiotin and a microplate format.

DNA was prepared by sonication (Yu et al., 2002). The 16S rRNA gene sequence was amplified by PCR (Takahashi et al., 2002) and sequenced with an automatic sequence analyser (ABI PRISM 377A; PE Applied Biosystems) using a PRISM Ready Reaction dye primer cycle sequencing kit (PE Applied Biosystems).

Species related to the novel isolate were determined by performing sequence database searches using BLAST. The sequence data of related species were retrieved from GenBank. Nucleotide substitution rates ( $K_{\text {nuc }}$ values) were calculated (Kimura \& Ohta, 1972) and phylogenetic trees were constructed by using the neighbour-joining method (Saitou \& Nei, 1987). The statistical significance of the tree topology was evaluated by bootstrap analysis of sequence data with CLUSTAL W software (Thompson et al., 1994). Sequence similarity values were determined by visual comparison and manual calculation.
Strains KV-628 ${ }^{\mathrm{T}}$, KV-641 and KV-656 were isolated from isolation GPM agar medium supplemented with SOD, catalase or SOD plus catalase. PCR amplification was performed to determine if these strains were members of the Actinobacteria. This test was established to distinguish strains of the Actinobacteria from both Gram-negative bacteria and Gram-positive bacteria with low-G + C DNA contents by taking advantage of the specific insertion of a $100 \mathrm{bp}$ sequence in domain III of the $23 \mathrm{~S}$ rRNA gene of the Actinobacteria. The PCR was designed to amplify a $\sim 380 \mathrm{bp}$ fragment from the Actinobacteria and a $\sim 270$ bp fragment from other bacteria (Roller et al., 1992; Yu et al., 2002). Amplicons of these strains were all $\sim 350 \mathrm{bp}$ in length, and the results showed that all three of the isolated strains were members of the Actinobacteria.

Nearly complete $16 \mathrm{~S}$ rRNA gene sequences were determined for the three isolated strains. A database search demonstrated that these strains belonged to the suborder Micrococcineae of the family Intrasporangiaceae. It was clear from the phylogenetic tree (Fig. 1) that the three strains formed a monophyletic clade loosely associated with Ornithinicoccus hortensis. The sequence similarity values among $\mathrm{KV}-628^{\mathrm{T}}$, KV-641 and KV-656 were above $99 \cdot 9 \%$, whereas the sequence similarity values between these three strains and Ornithinicoccus hortensis were below $95 \cdot 6 \%$. Sequence similarity values for $\mathrm{KV}-628^{\mathrm{T}}$ and other Intrasporangiaceae family members were as follows: Terrabacter tumescens, 95.2\%; Knoellia sinensis, 95.2\%; Intrasporangium calvum, 94. $8 \%$; Janibacter limosus, 94.8\%; Tetrasphaera japonica, 94.8\%; Arsenicicoccus bolidensis, 94.8\%; Terracoccus luteus, $94 \cdot 4 \%$; and Ornithinimicrobium humiphilum, $93 \cdot 7 \%$.

The three strains were also examined for a set of phenotypic and chemotaxonomic characteristics. Strains KV- $628^{\mathrm{T}}, \mathrm{KV}$ 641 and KV-656 were very similar in terms of morphological and chemotaxonomic characteristics. The three strains were irregular rods and the cell diameters varied from $0 \cdot 4$ to $0.9 \mu \mathrm{m}$ by 0.9 to $1.9 \mu \mathrm{m}$ (Fig. 2). The cells of the three strains were Gram-positive, catalase-positive and showed no motility. The strains were able to grow at $15-37^{\circ} \mathrm{C}$ and at $\mathrm{pH} 4-9$, but at $\mathrm{pH} 9$ only trace growth was observed. $\mathrm{NaCl}$ in $1 / 5$ nutrient agar medium was tolerated up to $4 \%$, while only trace growth was observed at $5 \% \mathrm{NaCl}$.

The physiological characteristics are given in the species description. The three isolated strains were very similar in terms of carbon-source assimilation and enzyme content.

The DNA G + C content of KV-628 ${ }^{\mathrm{T}}, \mathrm{KV}-641$ and KV-656 was $72-73 \mathrm{~mol} \%$ (with the HPLC nucleoside method). The cell-wall peptidoglycan of KV-628 ${ }^{\mathrm{T}}, \mathrm{KV}-641$ and KV-656 contained meso-diminopimelic acid, alanine and glutamic acid at molar ratios of $1 \cdot 0: 1 \cdot 6: 1 \cdot 0,1 \cdot 0: 1 \cdot 7: 1 \cdot 0$ and $1 \cdot 0: 1 \cdot 7: 1 \cdot 0$, respectively. The three isolated strains contained a peptidoglycan of type A $1 \gamma$ (Schleifer \& Kandler, 1972). The predominant menaquinone was MK- $8\left(\mathrm{H}_{4}\right)$. The acyl type was acetyl. Mycolic acids were not detected. The 


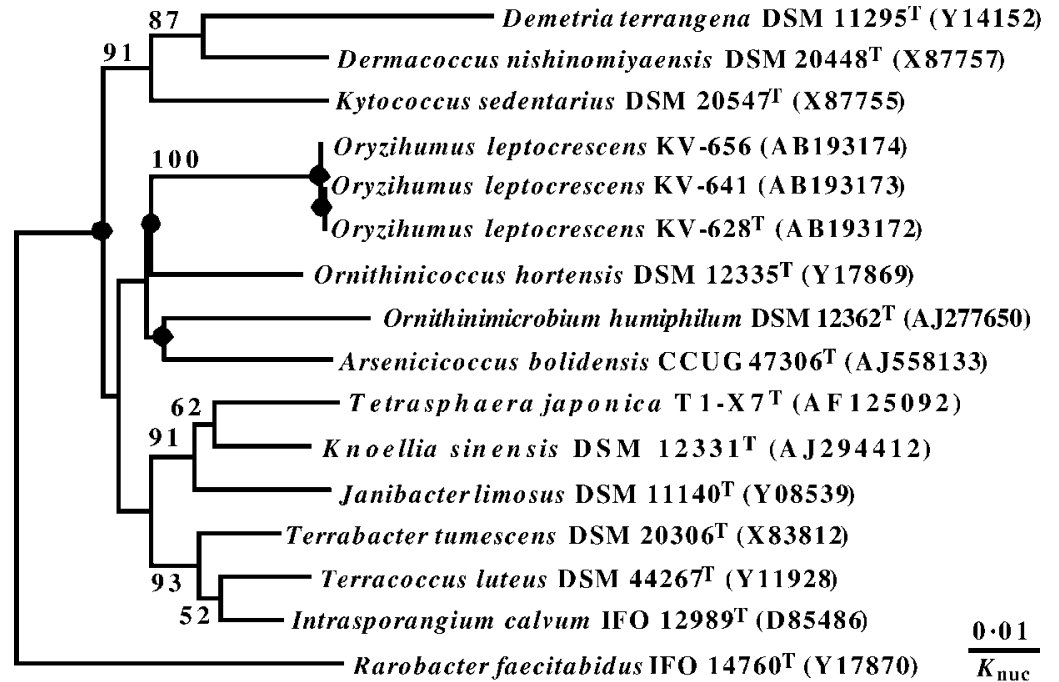

Fig. 1. Phylogenetic tree, derived from $16 \mathrm{~S}$ rRNA gene sequences, created using the neighbour-joining method and $K_{\text {nuc }}$ values. Only values above $50 \%$ significance are indicated. The solid circles indicate that the corresponding nodes are also recovered in the maximum-likelihood tree. The tree was unrooted and Rarobacter faecitabidus was used as an outgroup. predominant cellular fatty acids were iso- $\mathrm{C}_{14: 0}$, iso- $\mathrm{C}_{15: 0}$, anteiso- $\mathrm{C}_{15: 0}$ and iso- $\mathrm{C}_{16: 0}$ (Table 1 ).

To confirm that these strains belong to a novel species, DNA-DNA hybridization relatedness was determined. The levels of DNA-DNA relatedness among the three isolated strains and Ornithinicoccus hortensis were determined. The values among the three isolated strains were 90-101\%, whereas those between the three strains and Ornithinicoccus hortensis were below $25 \%$. The values were well below the $70 \%$ cut-off point recommended by Wayne et al. (1987) for species classification.

At present, the family Intrasporangiaceae contains nine genera: Arsenicicoccus (Collins et al., 2004), Intrasporangium (Kalakoutskii et al., 1967), Janibacter (Martin et al., 1997), Knoellia (Groth et al., 2002), Terrabacter (Collins et al., 1989), Terracoccus (Prauser et al., 1997), Tetrasphaera (Maszenan et al., 2000), Ornithinicoccus (Groth et al.,

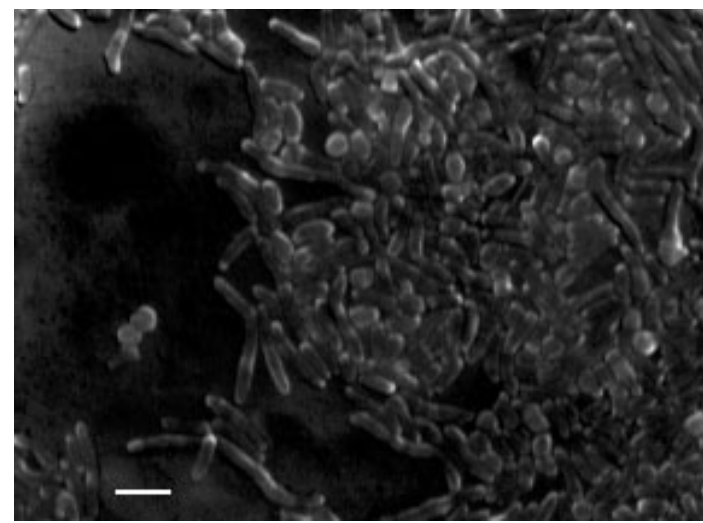

Fig. 2. Scanning electron micrograph of cells from a 6-day-old culture of strain $\mathrm{KV}-628^{\top}$ grown on GPM agar medium at $27^{\circ} \mathrm{C}$. Bar, $2 \mu \mathrm{m}$.
1999) and Ornithinimicrobium (Groth et al., 2001). Table 2 shows the differential characteristics of the members of the family Intrasporangiaceae. The genera Janibacter, Knoellia and Tetrasphaera also have meso-diaminopimelic acid in their cell walls, but Janibacter, Knoellia (iso- $\mathrm{C}_{15: 0}$, iso- $\mathrm{C}_{17: 0}$, iso- $\mathrm{C}_{16: 0}$ and anteiso- $\left.\mathrm{C}_{17: 0}\right)$ and Tetrasphaera differ in terms of cellular fatty acids.

On the basis of the distinct phylogenetic position of the three novel isolates within the family Intrasporangiaceae, as well as their differential characteristics in terms of cell morphology and cell-wall murein type, a novel genus and species, Oryzihumus leptocrescens gen. nov., sp. nov., is proposed.

\section{Description of Oryzihumus gen. nov.}

Oryzihumus (Ory.zi.hu' mus. L. fem. n. oryza rice; L. masc. n. humus soil; N.L. masc. n. Oryzihumus rice soil).

Table 1. Cellular fatty acid composition (\%) of strains $\mathrm{KV}-628^{\top}, \mathrm{KV}-641$ and $\mathrm{KV}-656$

Abbreviations for fatty acids are as follows: $\mathrm{C}_{16: 0}$, hexadecanoic acid; $\mathrm{i}-\mathrm{C}_{15: 0}$, 13-methyl tetradecanoic acid; ai- $\mathrm{C}_{15: 0}$, 12-methyl tetradecanoic acid.

\begin{tabular}{|lccc|}
\hline Fatty acid & KV-628 $^{\text {T }}$ & KV-641 & KV-656 \\
\hline i- $C_{13: 0}$ & - & $0 \cdot 5$ & - \\
i- $C_{14: 0}$ & $12 \cdot 9$ & $7 \cdot 7$ & $4 \cdot 8$ \\
$\mathrm{C}_{14: 0}$ & - & $1 \cdot 0$ & $2 \cdot 8$ \\
i- $C_{15: 0}$ & $23 \cdot 1$ & $40 \cdot 1$ & $27 \cdot 3$ \\
ai-C $15: 0$ & $3 \cdot 1$ & $10 \cdot 7$ & $14 \cdot 5$ \\
i-C $16: 0$ & $35 \cdot 8$ & $13 \cdot 7$ & $9 \cdot 4$ \\
C $_{16: 0}$ & $0 \cdot 6$ & $0 \cdot 7$ & $5 \cdot 2$ \\
i- $C_{17: 0}$ & $0 \cdot 5$ & $0 \cdot 9$ & $0 \cdot 6$ \\
ai- $C_{17: 0}$ & $1 \cdot 4$ & $5 \cdot 0$ & $5 \cdot 0$ \\
\hline
\end{tabular}


Table 2. Differential characteristics of strain $\mathrm{KV}-628^{\top}$ and related taxa

L-Orn, L-ornithine; meso- $\mathrm{A}_{2} \mathrm{pm}$, meso-diaminopimelic acid; LL- $\mathrm{A}_{2} \mathrm{pm}$, LL-diaminopimelic acid; A, anteiso methyl-branched; I, iso methylbranched; S, straight-chain saturated; U, monounsaturated.

\begin{tabular}{|c|c|c|c|c|c|c|}
\hline Taxon & Cell morphology & $\begin{array}{c}\text { Wall } \\
\text { diamino acid }\end{array}$ & $\begin{array}{c}\text { DNA G }+ \text { C } \\
\text { content }(\mathrm{mol} \%)\end{array}$ & $\begin{array}{c}\text { Murein } \\
\text { type }\end{array}$ & $\begin{array}{c}\text { Major } \\
\text { menaquinone }\end{array}$ & $\begin{array}{c}\text { Fatty } \\
\text { acid type }\end{array}$ \\
\hline $\mathrm{KV}-628^{\mathrm{T}}$ & Irregular rods & meso- $\mathrm{A}_{2} \mathrm{pm}$ & $72-73$ & $\mathrm{~A} 1 \gamma$ & MK-8 $\left(\mathrm{H}_{4}\right)$ & SAI \\
\hline Arsenicicoccus ${ }^{\star}$ & Cocci & $\mathrm{LL}-\mathrm{A}_{2} \mathrm{pm}$ & 72 & $\mathrm{~A} 3 \gamma$ & $\mathrm{MK}-8\left(\mathrm{H}_{4}\right)$ & SAIU \\
\hline Intrasporangium $\dagger$ & Hyphae & LL- $\mathrm{A}_{2} \mathrm{pm}$ & 68 & $\mathrm{~A} 3 \gamma$ & MK-8 & SAI \\
\hline Janibacter $\ddagger$ & Coccoid to rod-shaped & meso- $\mathrm{A}_{2} \mathrm{pm}$ & 70 & $\mathrm{~A} 1 \gamma$ & MK-8 $\left(\mathrm{H}_{4}\right)$ & SIU \\
\hline Knoellia\$ & Coccoid to rod-shaped & meso- $\mathrm{A}_{2} \mathrm{pm}$ & $68-69$ & $\mathrm{~A} 1 \gamma$ & MK-8 $\left(\mathrm{H}_{4}\right)$ & SAI \\
\hline Terrabacter $\ddagger$ & Cocci to rods & LL-A ${ }_{2} \mathrm{pm}$ & $70-73$ & $\mathrm{~A} 3 \gamma$ & MK-8 $\left(\mathrm{H}_{4}\right)$ & SAI \\
\hline Terracoccus I & Cocci & LL- $\mathrm{A}_{2} \mathrm{pm}$ & 73 & $\mathrm{~A} 3 \gamma$ & $\mathrm{MK}-8\left(\mathrm{H}_{4}\right)$ & SAI \\
\hline Tetrasphaera & Cocci & meso- $\mathrm{A}_{2} \mathrm{pm}$ & $68-71$ & $\mathrm{~A} 1 \gamma$ & $\mathrm{MK}-8\left(\mathrm{H}_{4}\right)$ & SAIU \\
\hline Ornithinicoccus\# & Cocci & L-Orn & 72 & $\mathrm{~A} 4 \beta$ & MK-8 $\left(\mathrm{H}_{4}\right)$ & SAI \\
\hline Ornithinimicrobium ${ }^{* *}$ & Cocci & L-Orn & 70 & $\mathrm{~A} 4 \beta$ & MK-8 $\left(\mathrm{H}_{4}\right)$ & SAI \\
\hline
\end{tabular}

${ }^{\star}$ Data from Collins et al. (2004).

$\dagger$ Data from Schumann et al. (1997).

$\ddagger$ Data from Martin et al. (1997).

§Data from Groth et al. (2002).

IIData from Prauser et al. (1997).

SData from Maszenan et al. (2000).

\#Data from Groth et al. (1999).

${ }^{*}$ Data from Groth et al. (2001).

Gram-positive, catalase-positive, aerobic, non-motile irregular rods. The peptidoglycan is of the A type of direct crosslinkage and contains meso-diaminopimelic acid, alanine and glutamic acid. The acyl type of the glycan chain of peptidoglycan is acetyl. Mycolic acids are absent. The major menaquinone is $\mathrm{MK}-8\left(\mathrm{H}_{4}\right)$. The DNA $\mathrm{G}+\mathrm{C}$ content is $72-73 \mathrm{~mol} \%$. Phylogenetically, this genus is a member of the family Intrasporangiaceae, suborder Micrococcineae. The type species is Oryzihumus leptocrescens.

\section{Description of Oryzihumus leptocrescens sp. nov.}

Oryzihumus leptocrescens (lep.to.cre'scens. Gr. adj. leptos thin, fine, delicate, slender; L. part. adj. crescens growing; N.L. part. adj. leptocrescens slender growing).

Cells are irregular rods $0 \cdot 4-0 \cdot 9 \mu \mathrm{m}$ by $0 \cdot 9-1 \cdot 9 \mu \mathrm{m}$. Colonies are pale yellow. Aerobic to microaerophilic. Growth occurs between $\mathrm{pH} 4$ and 9 and at 15 and $37^{\circ} \mathrm{C}$. In $1 / 5$ nutrient agar medium, $\mathrm{NaCl}$ is tolerated up to $5 \%$. D-Glucose, maltose, sucrose and trehalose are assimilated, but L-rhamnose and D-xylose are not. Susceptible to erythromycin $\left(15 \mu \mathrm{g} \mathrm{ml}^{-1}\right)$, rifampicin $\left(30 \mu \mathrm{g} \mathrm{ml}^{-1}\right)$, novobiocin $\left(30 \mu \mathrm{g} \mathrm{ml}^{-1}\right)$, streptomycin $\left(10 \mu \mathrm{g} \mathrm{ml}^{-1}\right)$ and chloramphenicol $\left(30 \mu \mathrm{g} \mathrm{ml}^{-1}\right)$. Not susceptible to aztreonam $\left(100 \mu \mathrm{g} \mathrm{ml}^{-1}\right)$. Esterase (C4), esterase lipase (C8), leucine arylamidase, valine arylamidase, acid phosphatase, naphthol-AS-BI-phosphohydrolase, $\beta$ galactosidase, $\alpha$-glucosidase and $\beta$-glucosidase are detected by the API ZYM enzyme assay; alkaline phosphatase, cystine arylamidase, trypsin, chymotrypsin, $\beta$-glucuronidase,
$N$-acetyl- $\beta$-glucosaminase, $\alpha$-mannosidase and $\alpha$-fucosidase are not detected. A weak reaction for lipase (C14) is detected. Variable reactions for $\alpha$-galactosidase are detected. The DNA G + C content is $72-73 \mathrm{~mol} \%$.

Habitat: paddy soil in Japan. The type strain is $\mathrm{KV}-628^{\mathrm{T}}$ $\left(=\right.$ NRRL B-24347 ${ }^{\mathrm{T}}=$ JCM $12835^{\mathrm{T}}=$ NBRC $\left.100762^{\mathrm{T}}\right)$.

\section{Acknowledgements}

This study was supported, in part, by a grant from the 21st Century COE Program from the Ministry of Education, Culture, Sports, Science and Technology (MEXT).

\section{References}

Becker, B., Lechevalier, M. P. \& Lechevalier, H. A. (1965). Chemical composition of cell-wall preparations from strains of various formgenera of aerobic actinomycetes. Appl Microbiol 13, 236-243.

Collins, M. D., Pirouz, T., Goodfellow, M. \& Minnikin, D. E. (1977). Distribution of menaquinones in actinomycetes and corynebacteria. J Gen Microbiol 100, 221-230.

Collins, M. D., Dorsch, M. \& Stackebrandt, E. (1989). Transfer of Pimelobacter tumescens to Terrabacter gen. nov. as Terrabacter tumescens comb. nov. and of Pimelobacter jensenii to Nocardioides as Nocardioides jensenii comb. nov. Int J Syst Bacteriol 39, 1-6.

Collins, M. D., Routh, J., Saraswathy, A., Lawson, P. A., Schumann, P., Welinder-Olsson, C. \& Falsen, E. (2004). Arsenicicoccus bolidensis gen. nov., sp. nov., a novel actinomycete isolated from contaminated lake sediment. Int J Syst Evol Microbiol 54, 605-608. 
Ezaki, T., Hashimoto, Y. \& Yabuuchi, E. (1989). Fluorometric deoxyribonucleic acid-deoxyribonucleic acid hybridization in microdilution wells as an alternative to membrane filter hybridization in which radioisotopes are used to determine genetic relatedness among bacterial strains. Int J Syst Bacteriol 39, 224-229.

Groth, I., Schumann, P., Martin, K., Schuetze, B., Augsten, K., Kramer, I. \& Stackebrandt, E. (1999). Ornithinicoccus hortensis gen. nov., sp. nov., a soil actinomycete which contains L-ornithine. Int J Syst Bacteriol 49, 1717-1724.

Groth, I., Schumann, P., Weiss, N., Schuetze, B., Augsten, K. \& Stackebrandt, E. (2001). Ornithinimicrobium humiphilum gen. nov., sp. nov., a novel soil actinomycete with L-ornithine in the peptidoglycan. Int J Syst Evol Microbiol 51, 81-87.

Groth, I., Schumann, P., Schuetze, B., Augsten, K., Kramer, I. \& Stackebrandt, E. (2002). Knoellia sinensis gen. nov., sp. nov. and Knoellia subterranea sp. nov., two novel actinobacteria isolated from a cave. Int J Syst Evol Microbiol 52, 77-84

Hasegawa, T., Takizawa, M. \& Tanida, S. (1983). A rapid analysis for chemical grouping of aerobic actinomycetes. J Gen Appl Microbiol 29, 319-322.

Huck, T. A., Porter, N. \& Bushell, M. E. (1991). Positive selection of antibiotic-producing soil isolates. J Gen Microbiol 137, 2321-2329.

Iwai, Y. \& Takahashi, Y. (1992). Selection of microbial sources of bioactive compounds. In The Search for Bioactive Compounds from Microorganisms, pp. 281-302. Edited by S. Ōmura. New York: Springer.

Jiang, C.-L. \& Xu, L.-H. (1996). Diversity of aquatic actinomycetes in lakes of the middle plateau, Yunnan, China. Appl Environ Microbiol 62, 249-253.

Kalakoutskii, L. V., Kirillova, I. P. \& Krasil'Nikov, N. A. (1967). A new genus of the Actinomycetales, Intrasporangium gen. nov. J Gen Microbiol 48, 79-85.

Kawamoto, l., Oka, T. \& Nara, T. (1981). Cell wall composition of Micromonospora olivoasterospora, Micromonospora sagamiensis, and related organisms. J Bacteriol 146, 527-534.

Kimura, M. \& Ohta, T. (1972). On the stochastic model for estimation of mutation distance between homologous proteins. $J \mathrm{Mol}$ Evol 2, 87-90.

Martin, K., Schumann, P., Rainey, F. A., Schuetze, B. \& Groth, I. (1997). Janibacter limosus gen. nov., sp. nov., a new actinomycete with meso-diaminopimelic acid in the cell wall. Int J Syst Bacteriol 47, 529-534.

Maszenan, A. M., Seviour, R. J., Patel, B. K. C., Schumann, P., Burghardt, J., Tokiwa, Y. \& Stratton, H. M. (2000). Three isolates of novel polyphosphate-accumulating Gram-positive cocci, obtained from activated sludge, belong to a new genus, Tetrasphaera gen. nov., and description of two new species, Tetrasphaera japonica sp. nov. and Tetrasphaera australiensis sp. nov. Int J Syst Evol Microbiol 50, 593-603.

Minnikin, D. E., Patel, P. V., Alshamony, L. \& Goodfellow, M. (1977). Polar lipid composition in the classification of Nocardia and related bacteria. Int J Syst Bacteriol 27, 104-117.

Nioh, I., Osada, M., Yamamura, T. \& Muramatsu, K. (1995). Acidophilic and acid-tolerant actinomycetes in an acid tea field soil. J Gen Appl Microbiol 41, 175-180.

Nonomura, H. \& Hayakawa, M. (1988). New methods for the selective isolation of soil Actinomycetes. In Biology of Actinomycetes '88, pp. 288-293. Edited by Y. Okami, T. Beppu \& H. Ogawara. Tokyo: Japan Scientific Societies.
Prauser, H., Schumann, P., Rainey, F. A., Kropppenstedt, R. M. \& Stackebrandt, E. (1997). Terracoccus luteus gen. nov., sp. nov., an LL-diaminopimelic acid-containing coccoid actinomycete from soil. Int J Syst Bacteriol 47, 1218-1224.

Pridham, T. G. \& Gottlieb, D. (1948). The utilization of carbon compounds by some Actinomycetales as an aid for species determination. J Bacteriol 56, 107-114.

Roller, C., Ludwig, W. \& Schleifer, K. H. (1992). Gram-positive bacteria with a high DNA $\mathrm{G}+\mathrm{C}$ content are characterized by a common insertion within their 23S rRNA genes. J Gen Microbiol 138, 1167-1175.

Saito, H. \& Miura, K. (1983). Preparation of transforming deoxyribonucleic acid by phenol treatment. Biophys Acta 72, 619-629.

Saitou, N. \& Nei, M. (1987). The neighbor-joining method: a new method for reconstructing phylogenetic trees. Mol Biol Evol 4, 406-425.

Schleifer, K. H. \& Kandler, O. (1972). Peptidoglycan types of bacterial cell walls and their taxonomic implications. Bacteriol Rev 36, 407-477.

Schumann, P., Prauser, H., Rainey, F. A., Stackebrandt, E. \& Hirsch, P. (1997). Friedmanniella antarctica gen. nov., sp. nov., an LLdiaminopimelic acid-containing actinomycete from Antarctic sandstone. Int J Syst Bacteriol 47, 278-283.

Suzuki, K. \& Komagata, K. (1983). Taxonomic significance of cellular fatty acid composition in some coryneform bacteria. Int J Syst Bacteriol 33, 188-200.

Suzuki, S., Takahashi, K., Okuda, T. \& Komatsubara, S. (1998). Selective isolation of Actinobispora on gellan gum plate. Can J Microbiol 44, 1-5.

Takahashi, Y., Matsumoto, A., Seino, A., Iwai, Y. \& Ōmura, S. (2002). Streptomyces avermectinius sp. nov., an avermectin-producing strain. Int J Syst Evol Microbiol 52, 2163-2168.

Takahashi, Y., Katoh, S., Shikura, N., Tomoda, H. \& Ōmura, S. (2003).Superoxide dismutase produced by soil bacteria increases bacterial colony growth from soil samples. J Gen Appl Microbiol 49, 263-266.

Takeuchi, M. \& Hatano, K. (1999). Phylogenetic analysis of Actinobacteria in the mangrove rhizosphere. IFO Res Commun 19, 47-62.

Tamaoka, J. \& Komagata, K. (1984). Determination of DNA base composition by reversed-phase high-performance liquid chromatography. FEMS Microbiol Lett 25, 125-128.

Tamaoka, J., Katayama-Fujimura, Y. \& Kuraishi, H. (1983). Analysis of bacterial menaquinone mixtures by high performance liquid chromatography. J Appl Bacteriol 54, 31-36.

Thompson, J. D., Higgins, D. G. \& Gibson, T. J. (1994). CLUSTAL W: improving the sensitivity of progressive multiple sequence alignment through sequence weighting, position specific gap penalties and weight matrix choice. Nucleic Acids Res 22, 4673-4680.

Tomiyasu, I. (1982). Mycolic acid composition and thermally adaptative changes in Nocardia asteroides. J Bacteriol 151, 828-837.

Uchida, K. \& Aida, K. (1977). Acyl type of bacterial cell wall: its simple identification by a colorimetric method. J Gen Appl Microbiol 23, 249-260.

Wayne, L. G., Brenner, D. J., Colwell, R. R. \& 9 other authors (1987). International Committee on Systematic Bacteriology. Report of the ad hoc committee on reconciliation of approaches to bacterial systematics. Int J Syst Bacteriol 37, 463-464.

Yu, L., Takahashi, Y., Matsumoto, A., Seino, A., Iwai, Y. \& Ōmura, S. (2002). Application of PCR for selection of gram-positive bacteria with high DNA G + C content among new isolates. Actinomycetologica 16, 1-5. 